the evening as the church bells rang, I was able to see the beautiful singer while actually recording its song. It was a male Golden-winged Warbler and visible for at least 30 seconds. The audiospectrogram of the song given on p. 254 of Birds of North America (Robbins, Bruun, Zim and Singer, 1966) is identical with the song I recorded-1 $1 \frac{1}{3}$ seconds duration at a pitch of 4300 to 7500 cycles. Incidentally, on this occasion, I recorded another song which I have not yet been able to identify.

In the fifth edition of the A.O.U. Check-list of North American birds (1957) the breeding range of the Golden-winged Warbler is given as southeastern Manitoba, then eastward and southward in North America. The only other record that we have for Saskatchewan is a sight record by a single observer, Frank Brazier, of a bird seen in Regina on May 18, 1962, and reported in the Blue Jay, 20: 153-4. Being able to record the song of the bird which I had the good fortune to see and hear on June 2, 1968 adds substantially to the evidence of the occurrence of this species in Saskatchewan.

With the tape recorder one is able to identify birds accurately by making recordings of the singer. One can be as accurate in identification as with specimen records, and much more accurate than many records published from hasty sight records. It is known that some birds imitate others, but as mentioned, when a sufficient sample of the song of the individual bird has been taken this method of identification can be positive. Birds sing with various levels of perfection. Tape recorders can capture the sounds of different environments. This is an excellent way to get acquainted with the birds before the spring migration begins, which is always necessary, even to the experienced ornothologist. The more one becomes familiar with sounds the more one realizes their value and the genuine pleasure that can be had from these records. It is much more personal than seeing, and impresses you more. I hope others will take advantage of the facilities that are available in the use of this type of machine. I'm satisfied that it can be of as much pleasure to the amateur as to the professional, and a good deal cheaper than photography -an equally interesting profession. This recorder is adaptable to a variety of uses. When patch cords are used to playback over a high-fi, the quality and volume are again most surprising. This is one of the simplest operating tape recorders, with amazing quality. I highly recommend it.

\title{
THE HARLEQUIN DUCK IN SASKATCHEWAN
}

\section{by D. F. Brunton, Ottawa, Ontario}

A Harlequin Duck (Histrionicus histrionicus) in the portion of the Prairie Provinces east of the Rockies is a rare occurrence indeed. Godfrey (Birds of Canada, 1966) cites only five records for this area. However, on a birding trip to Regina, Saskatchewan this fall, I was able to add another record to this list.

On a morning trip around Wascana Lake in Regina on September 6, 1968, I spotted three of these small ducks. The Harlequins were flushed from the reeds on the north side of the lake by the Broad Street bridge.
They were exceedingly tame and allowed a close study through $7 \times 50$ binoculars at a distance of approximately 35 feet.

At 1:00 p.m. I returned with $\mathrm{Mr}$. F. Brazier of the Saskatchewan Natural History Society and we again spotted the birds; at this time they were asleep, well out in the open water. Soon after, Mr. F. Bard of the Saskatchewan Museum of Natural History came over and we were able to study them closely, to the point where we were entirely satisfied that they were Harlequin Ducks. I was 
able to observe them until almost 4:00 p.m. They were not seen after this time.

The birds appeared to be adult males in eclipse plumage. Although they had the characteristic white head spots of the female, the brilliance of the spots was quite different. The small posterior head spot was the brightest; the large spot below the bill was fainter, and the upper bill spot was at times very difficult to see. The birds had a purple wash across the breast and a red-brown coloration on the dark sides. Although they slept most of the day, they did come alive about 2:00 p.m. and were heard to give a series of "Wheet"-like call notes.

There is only one previous record for Harlequin Ducks in Saskatchewan. A mounted male in the Swift Current Collegiate Museum is mentioned in the Blue Jay, 16:65, where it is re- corded that "several pairs of Harlequin Ducks were reported at the Saskatchewan Landing Ferry. A beautiful male specimen was taken on May 31 (1934) ..."

Although I have sean Harlequins before, on the coast of British Columbia, they too were in fall plumage. The British Columbia observation helped me in identifying the birds in this instance, but I wish, on aesthetic grounds, that these birds had still been in possession of their spectacular breeding plumage!

EDITOR'S NOTE: After receiving the above note from Mr. Brunton, we were informed of a second and later sighting of a Harlequin Duck in Regina. This later observation was made by Fred Lahrman, Bill Eddie and Lorne Scott of the Saskatchewan Museum of Natural History at the Condie Park on Highway \#11 just northwest of the city of Regina on October 10,1968 . Lahrman was close enough to photograph the bird and to note the one distinct white spot behind the eye and the lighter shading at the base of the bill. The bird was again sighted on October 22 , and it was shown to me on October 23 by Lorne Scott.-Margaret Belcher.

\section{ADDITIONAL BIRD SPECIES FOR CREE LAKE}

by D. Wayne Davis, The School of the Ozarks, Point Lookout, Missouri; and W. Harvey Beck, Manitoba Museum of Man and Nature, Winnipeg

The Sharp-tailed Grouse (Pedioecetes phasianellus) was earlier reported as a hypothetical occasional visitor to Cree Lake (Davis, 1966). During a visit to Cree Lake in June, 1966, we asked trapper Martin Engeman to collect a specimen. Martin saw none during the fall or winter of 1966 but saw and collected a single specimen in late November of 1967. The rather dark-colored specimen was mounted by Miss Doris Montgrant and was donated to the Saskatchewan Museum of Natural History. It was identified as belonging to the subspecies caurus by W. Earl Godfrey of the National Museum, Ottawa, who commented that it would be interesting to know how far east caurus is found as a breeding bird. The Sharptailed Grouse is listed as an uncommon permanent resident of the Lake Athabasca region (Nero, 1963).

On June 25, 1966, we observed a
Common Snipe (Capella gallinago) winnowing on the west side of Lazy Edward Bay. An Eastern Kingbird (Tyrannus tyrannus) was seen nearby. Tree Swallows (Iridoprocne bicolor) were seen on both the west and east sides of Lazy Edward Bay. Martin Brustad, who trapped and fished at Cree Lake for many years, said that bluebirds (Mountain Bluebirds?) nested in boxes he had built at his cabin at Stony Narrows. The above species were not reported by Lahrman (1953) or Davis (1966) for Cree Lake although both species occur farther north in the Lake Athabasca region (Nero, 1963).

\section{LITERATURE CITED}

Davis, D. W. 1966. Some observations of birds at Cree Lake, Saskatchewan. Blue Jay, 24 : 80-85.

Lahrman, F. W. 1964. The bird life at Cree Lake, summer 1963. Blue Jay, $22: 7-8$.

Nero, R. W. 1963. Birds of the Lake Athabasca region, Saskatchewan. Spec. Pub. No. 5, Sask. Nat. Hist. Soc., Regina, 143 pp. \& 12 plates. 